\title{
Determinants of R\&D offshoring: firm-level evidence from a small open economy
}

\author{
Gavin Murphy ${ }^{1} \cdot$ Iulia Siedschlag ${ }^{2,3,4} 4_{\mathbb{C}}$
}

Received: 14 June 2017 / Accepted: 26 February 2018 / Published online: 3 March 2018 (C) The Author(s) 2018. This article is an open access publication

\begin{abstract}
We analyse determinants of an enterprise's decision to offshore R\&D activities using a novel dataset for enterprises in Ireland over the period 2001-2006. Our results suggest that, on average, other things equal, enterprises integrated in international production and innovation networks, and enterprises which used information and communication technologies more intensively were more likely to offshore R\&D. Furthermore, characteristics of the import source region had an important influence on enterprise offshoring behaviour, with offshoring to regions outside of the advanced European Union's economies being less likely.
\end{abstract}

Keywords Global production and innovation networks - International sourcing of $\mathrm{R} \& \mathrm{D}$

The views expressed are purely those of the authors and may not in any circumstances be regarded as stating an official position of the European Commission or the Department of Finance. This research has been funded by the European Commission under the $7^{\text {th }}$ Framework and Horizon 2020 for Research and Innovation Programmes. This research uses statistical data from the Central Statistics Office (CSO) of Ireland. The permission for controlled access to confidential micro data sets has been granted in line with the Statistics Act, 1993. The use of these statistical data does not imply the endorsement of the CSO in relation to the analysis or interpretation of the statistical data. We thank Tommaso Aquilante, Luigi Benfratello, Eva Hagsten, Bernhard Dachs, Ibrahim Rohman, participants at the Annual Conference of the European Trade Study Group in Munich, and the research workshop on "Global Value Chains in Europe" at the University of Birmingham for helpful comments and suggestions on an earlier version. We also thank Mattia Di Ubaldo for his generous help with Stata coding.

Iulia Siedschlag

iulia.siedschlag@esri.ie

1 Department of Finance, Dublin, Ireland

2 Economic and Social Research Institute, Dublin, Ireland

3 Department of Economics, Trinity College Dublin, Dublin, Ireland

4 European Commission, Joint Research Centre, Seville, Spain 
JEL Classification $F 14 \cdot F 23 \cdot D 22$

\section{Introduction}

Over the past two decades, technological advances have led to the reduction of transport and communication costs which in turn have enabled a greater fragmentation and internationalisation of production. In recent years, there has been an increasing trend in the international outsourcing of R\&D. While the internationalisation of $\mathrm{R} \& \mathrm{D}$ is not new, its prevalence has increased in recent years in response to intensified global competition, technological change, and the availability and costs of skills (Abramovsky et al. 2008; Siedschlag et al. 2013). While the traditional role of foreign $\mathrm{R} \& \mathrm{D}$ investment has been demand-driven, linked to adapting products and services to local market conditions, knowledge-sourcing has become an important supply-driven motivation for investing in R\&D internationally (Ambos 2005; Ito and Wakasugi 2007; Belderbos et al. 2008; OECD 2008; Siedschlag et al. 2013; Dachs 2014).

Notwithstanding a growing research interest on understanding the determinants and impacts of the internationalisation of corporate R\&D and innovation, systematic evidence to inform research and innovation policies is still limited. This paper contributes to filling this gap by providing empirical evidence on links between firm and location characteristics and the propensity of enterprises to offshore R\&D and other business activities. While the main objective of this analysis is uncovering determinants of R\&D offshoring, examining what drives the offshoring of other business functions helps to better understand any specificities of offshoring R\&D. To this purpose, we use a novel data set obtained by linking three enterprise surveys conducted by the Central Statistics Office (CSO) of Ireland: the International Sourcing Survey (ISS), the Census of Industrial Production (CIP), and the Annual Services Inquiry (ASI). This evidence informs enterprise strategy and policy design targeted at maximizing benefits from global sourcing of $R \& D$ and integration in global value chains.

In this analysis, offshoring or international sourcing is defined as in the ISS, namely "the total or partial movement of business functions currently performed in-house or currently domestically sourced by the resident enterprise to either nonaffiliated or affiliated enterprise located abroad".

Ireland is one of the most globalised economies in the world. ${ }^{1}$ Given the extensive engagement of its firms in international sourcing, Ireland is a relevant case for the purpose of our analysis. Among the countries covered by the International Sourcing Survey in $2007,{ }^{2}$ Ireland had the highest proportion of

\footnotetext{
${ }^{1}$ The 2017 edition of the KOF Index of Globalisation ranks Ireland second after the Netherlands among 207 countries. Ireland ranks second after Singapore with respect to economic globalisation. The rankings are based on data for 2014.

${ }^{2}$ The other countries surveyed in 2007 were: the Czech Republic, Denmark, Finland, Germany, Italy, the Netherlands, Portugal, Slovenia, Sweden, United Kingdom, and Norway. The reference period covered by the survey was 2001-2006. Alajääskö (2009) discusses the key findings from the International Sourcing Survey 2007.
} 
firms ${ }^{3}$ engaged in international sourcing of business activities, 38\%. In comparison, the corresponding EU average was $15 \%$. The proportion of firms with international sourcing of R\&D over the same reference period was $6.2 \%$ in Ireland, three times higher than the corresponding EU average, 2.1\%.

This research finds that, on average other things equal, larger, more productive enterprises, enterprises with international experience (foreign-owned and indigenous exporters), and enterprises with higher information and communication technologies (ICT) investment per employee and those which had a website were more likely to offshore business activities. The characteristics of the import source region appear to matter, with offshoring to regions outside the advanced European Union's economies (EU15) ${ }^{4}$ being less likely. In addition, we find that core business activities were more likely to be offshored compared with other business functions.

Relative to offshoring of core business functions, on average, offshoring of R\&D is less likely by 6.4 percentage points. Further, our results indicate that on average, other things equal, similarly to all the other business functions, offshoring of R\&D is more likely in the case of foreign-owned enterprises and from advanced EU15 countries. Unlike the offshoring of core business activities and similarly to all the other business functions, indigenous exporters are more likely than non-exporters to offshore R\&D. It appears that size and productivity do not matter for the decision to offshore $R \& D$ as is the case for offshoring of core business activities and engineering. These results suggest that, $R \& D$ offshoring is of strategic importance similarly with the case of offshoring of core business and engineering activities. Also, as is the case with offshoring of core business functions, distribution and engineering activities, offshoring of R\&D is more likely by enterprises located in the Southern and Eastern region which include the capital region. Enterprises having a website are more likely to offshore R\&D and this is also the case for offshoring of core and engineering activities.

The rest of this paper is structured as follows. Section 2 discusses the theoretical and empirical underpinnings of our analysis and distinguishes the determinants of $\mathrm{R} \& \mathrm{D}$ offshoring in comparison to those of offshoring of other business functions. Next, in Sect. 3 we discuss the data that we use. Section 4 presents our empirical methodology. Section 5 discusses the empirical results. Finally, Sect. 6 concludes.

\section{Theoretical and empirical framework}

In this section we discuss theoretical and empirical insights that underpin our analysis of determinants of offshoring of R\&D. To contextualise the determinants of offshoring of R\&D, we discuss first the more general case of offshoring of business activities.

\footnotetext{
3 The surveyed firms included those with 100 and more employees.

${ }^{4}$ Austria, Belgium, Denmark, Finland, France, Germany, Greece, Italy, Luxembourg, the Netherlands, Portugal, Spain, Sweden, United Kingdom.
} 
The decision to outsource certain business activities previously undertaken inhouse has been first analysed by Coase (1937). However, the interest in understanding factors driving international outsourcing or "offshoring" is more recent (Grossman and Helpman 2002; Antràs and Helpman 2004; Grossman and Rossi-Hansberg 2008).

One of the main motivations for offshoring identified in the theoretical literature is the opportunity for enterprises to save on production costs. Grossman and RossiHansberg (2008) develop a model that examines the potential productivity gains which accrue from offshoring that are motivated by international factor cost differentials. In their model, firms can benefit from labour cost differentials in different countries by offshoring tasks that are produced by low skilled labour more cheaply abroad than at home. However, the benefits of offshoring must be weighed against the coordination and monitoring costs of completing the task abroad. They find that firms that use low skilled labour intensively can gain relatively more in terms of profits and productivity and increase demand for the less offshorable labour inputs.

In the closely related theoretical literature on the determinants of the firm's organisation mode, Grossman and Helpman (2002) and Antràs and Helpman (2004) are particularly relevant. Grossman and Helpman (2002) examine the choice between outsourcing and firm integration. In determining their organisational mode, firmswhich are assumed to be equally productive- are faced with the trade off between the costs of running a large and less specialised organisation versus the search and monitoring costs of an input supplier. The authors show that outsourcing is likely to be more prevalent in some industries than in others. Outsourcing is more likely to be viable in large firms and in large economies. Also, in competitive markets outsourcing requires a high per unit cost advantage for specialised input producers relative to integrated firms, while in markets with less competition, outsourcing depends on the comparison of the fixed costs between specialised producers and integrated firms.

Antràs and Helpman (2004) model organisation choices of profit-maximising firms, accounting for the behaviour of the input supplier, given imperfect contract enforcement. Each input sourcing mode is associated with a respective fixed cost which only the more productive firms can overcome. In this framework, decisions regarding trade, investment and organisational choices are interdependent. Görg et al. (2008) also emphasise that "better" firms are more likely to offshore given that upfront sunk costs are involved. Wagner (2011) analyses the effects of offshoring on the performance of German manufacturing firms and shows that "better" firms self-select into offshoring. He identifies offshoring firms as being larger, more productive, more human capital intensive and more export intensive relative to nonoffshoring firms.

We earlier acknowledged that the most productive firms are capable of overcoming the fixed costs associated with offshoring. Implicit in our discussion was that the source country characteristics affect the cost of offshoring and influence the offshoring decision. Also the costs of offshoring to potential source countries are likely to differ by source country. The movement towards greater global integration through trade agreements involving the reduction of tariffs and non-tariff barriers between countries has had a dramatic impact on trade costs between countries. This, in turn, has increased the relative viability of offshoring to countries covered by such 
agreements. However, with the elimination of these trade barriers one could argue that the scope for potential gains from future trade agreements is more limited. In this context, a recent strand of the literature emphasises the importance of country trade facilitation characteristics such as the efficiency of customs, ports, transport infrastructure, regulation, and ICT infrastructure. Such factors influence the speed, efficiency and cost with which inputs are delivered and are particularly important in global supply chains where delays and costs can be transmitted throughout the value chains, Nordås (2006).

Access to skilled talent and specialised technologies in the source country are also expected to influence firms' offshoring behaviour. These factors are strategic considerations faced by firms which enable them to benefit from the science and technology infrastructure of the host country (Farrell et al. 2006; Bunyaratavej et al. 2007; Manning et al. 2008; Ceci and Masciarelli 2010).

Bunyaratavej et al. (2007) investigate the determinants of the location of services offshoring. Drawing on the international business research, they identify the cost of doing business abroad, liability of foreignness and institutional factors as defining the rationale for offshoring. Lower labour costs and human capital are found to matter in choosing a location for services outsourcing while the use of telecommunications technology lessens the need of firms to be near major markets. In line with the institutional theory literature, which emphasises the role institutions play in lowering transaction costs and information costs and facilitating interactions, they find that firms have a higher propensity to offshore to locations where culture, education and infrastructure closely resemble their home country.

The specific role of information and communication technology (ICT) on the offshoring activity of firms has come in for particular attention in the literature. This is unsurprising given it is considered one of the key drivers of global trade and financial integration (Rae and Sollie 2008). There are a number of channels through which ICT can directly reduce trade-related costs of offshoring. ${ }^{5}$ First, ICT, which is a General Purpose Technology, enables sellers to adapt and tailor their service to closely match the requirements of the buyers of the service. Second, ICT better facilitates the matching of producers and purchasers (Grossman and Helpman 2002). Finally, Autor et al. (2003) argue that ICT allows for the compartmentalisation of jobs into tasks some of which may be offshorable.

The empirical literature which examines the link between ICT and offshoring at the enterprise level is limited, but results tend to suggest a positive relationship (Abramovsky and Griffith 2006; Rasel 2012; Tomiura 2005). ${ }^{6}$ Abramovsky and Griffith (2006) investigate the effect of ICT on the enterprise's choice of organisational form for a sample of UK enterprises for the period 2001-2002. They show that enterprises with greater ICT investment and enterprises which order goods and services online are more likely to outsource and offshore business services. More recently, Rasel (2012) examines the relationship between ICT usage and enterprises'

\footnotetext{
${ }^{5}$ For a more extensive review of the impact of ICT on offshoring, see Rasel (2012).

${ }^{6}$ Benfratello et al. (2009), in their analysis of a sample of Italian firms, find the relationship between ICT investment and offshoring to be negative.
} 
offshoring decisions. She distinguishes between the types of ICT used by the enterprise and whether the ICT-offshoring relationship differs between manufacturing and services enterprises. Basing her analysis on the ICT Survey 2010 of German enterprises, she finds that enterprises that use more software systems (i.e. ICT intensive enterprises) are more likely to offshore compared with less ICT intensive enterprises. The use of software solutions for supply chain management systems is particularly important for manufacturing enterprises who decide to offshore. For service enterprises, Enterprise Resource Planning software and e-commerce purchases are also found to be relevant for offshoring.

Biewen et al. (2012) analyse the impact of cost pressures and financial constraints on the decision to offshore services for German multinational enterprises over the period 2002-2008. They find that an enterprise is less likely to begin offshoring if it faces internal cost pressures due to a drop in sales and sales per employee, while enterprises who already offshore are likely to intensify the offshoring activity. External credit conditions appear to have no significant impact on the offshoring activity. They also find that firms source from countries with high GDP and low wages in the sector that supplies the service.

In comparison to offshoring of other business functions, offshoring of $R \& D$ is more strategic in relation to future technological competences and at the same time more challenging in terms of contracting out given the inherent uncertainty of results (OECD 2008; Jabbour and Zuniga 2016). While R\&D offshoring has been initially associated with the internationalisation of $R \& D$ activities by multinational enterprises (Le Bas and Sierra 2002; Ambos 2005; Lewin et al. 2009; Siedschlag et al. 2013), over the past decade, indigenous firms, including small and medium sized enterprises have increasingly engaged in cross-border R\&D activities (OECD 2008; Nieto and Rodríguez 2011; Tamayo and Huergo 2017).

The literature identifies two main motivations for R\&D offshoring (Patel and Vega 1999; Le Bas and Sierra 2002; Nieto and Rodríguez 2011). Initially, the location of R\&D activities abroad has been linked to supporting manufacturing activities mainly driven by the need to adapt products and processes to local markets-home-base asset-exploiting R\&D (Kuemmerle 1999; Cantwell and Mudambi 2005). These R\&D activities are driven by demand in foreign markets and exploit technological assets developed by the parent company at home. A more recent motivation for offshoring $\mathrm{R} \& \mathrm{D}$ has been related to sourcing science and technology abroad in order to augment assets at home. This motivation is supply-driven and it is associated with seeking and exploiting location-specific advantages such as access to skills and new technology at lower cost or access to more diverse and complementary sources of knowledge and technologies (Le Bas and Sierra 2002; von Zedtwitz and Gassmann 2002; Iwasa and Odagiri 2004; Sachwald 2008; Shimizutani and Todo 2008; Jabbour and Zuniga 2016; Siedschlag et al. 2013). The fragmentation of the R\&D and the emergence of global innovation networks also provide firms with greater efficiency and flexibility (Bardhan 2006; Manning et al. 2008; Nieto and Rodríguez 2011).

International outsourcing of $\mathrm{R} \& \mathrm{D}$ allows firms to access specialised knowledge to accelerate product innovation and shorten product life cycles (Cesaroni 2004). However, sourcing R\&D internationally may involve non-trivial integration as well as monitoring and co-ordination costs (Veugelers 1997; Veugelers and Cassiman 
1999). Existing evidence suggests that the propensity to outsource R\&D internationally is higher for firms integrated in global production and innovation networks, i.e. exporters and foreign affiliates (García-Vega and Huergo 2011; Jabbour and Zuniga 2009, 2016; Tamayo and Huergo 2017).

García-Vega and Huergo (2011) focus on the role of trade in fostering R\&D offshoring. More specifically, they build on Antràs and Helpman (2004) and Helpman et al. (2004) and put forward a theoretical model of monopolistic competition with heterogeneous firms that explains offshoring of R\&D under financing constraints and technology leakage. In the context of open economies which trade internationally, the model produces three key predictions: (1) R\&D offshoring is more likely in the case of exporters than non-exporters; this result is driven by the fact that exporters are less financially constrained and are in a better position to bear the high transaction fixed costs of R\&D offshoring given that they sell in a larger market and have a larger volume of activity; (2) financing constraints reduce the probability of R\&D offshoring relatively more in the case of non-exporters than exporters; (3) $\mathrm{R} \& \mathrm{D}$ offshoring by exporters is more sensitive to the lack of technology or market information to monitor technology leakage than in the case of R\&D offshoring by non-exporters. This result reflects the fact that exporters face larger losses than nonexporters when there are technology leakages. The results of their empirical analysis are consistent with these theoretical predictions suggesting that public policies aiming to promote international acquisitions of R\&D should take into account the engagement of firms in international trade as well the strength of intellectual property rights in the source countries.

Martinez-Noya et al. (2012) examine what determines the choice of firms to offshore R\&D and what determines the location choice of offshored R\&D services. Their results indicate that the probability of offshoring $R \& D$ is positively linked to firms' technological capabilities and international experience. Further, they find that offshoring of R\&D for knowledge/technology sourcing purposes are more likely from developed countries.

Jabbour and Zuniga (2016) finds that R\&D offshoring by manufacturing in France is driven by a combination of technology sourcing and exploitation of homebased assets. Firms which offshore R\&D are more knowledge-intensive, more productive and more integrated in international markets than firms with no offshoring of R\&D. While firms with R\&D offshoring are good performers, they are located in industries which are lagging behind the global technological frontier.

Tamayo and Huergo (2017) find that the probability to offshore R\&D is positively linked to firms' size, firms' engagement in exporting, international technological cooperation, foreign ownership, continuous engagement in $R \& D$, and patent applications. Further, they examine the extent to which determinants of R\&D offshoring differ for independent firms and for firms which are part of a group, focusing on access to finance and information management. Their empirical results indicate that financing constraints are more binding in the case of independent firms. In addition, they find that the lack of information is relatively more binding for external R\&D offshoring than for offshoring within the firm.

In summary, our review of the theoretical and empirical literature highlights factors both internal and external to the enterprise which are likely to influence its 
offshoring decision, including offshoring of R\&D. Factors internal to the enterprise include labour productivity, size, technological capabilities, ICT investment and usage, human capital intensity, international trading experience, ownership. Factors external to enterprise that are likely to matter include the competitive pressure faced by the enterprise in an industry, other industry characteristics, host country characteristics and the location of the sourcing enterprise. The influence of these factors may differ depending on the type of business function offshored. Also the determinants of the offshoring activity may differ for manufacturing and services firms. Given the strategic nature of the decision to offshore R\&D, we expect some of these determinants to be stronger than in the case of the offshoring of other business functions. Such factors include for example, human capital, and international experience.

\section{Data and summary statistics}

To conduct our analysis, we merge data from three separate enterprise level surveys collected by the Central Statistics Office of Ireland. The datasets we use are the International Sourcing Survey (ISS), the Annual Services Inquiry (ASI) and the Census of Industrial Production (CIP). The ISS provides information on enterprise domestic outsourcing and offshoring activities and the factors that influence such behaviour over the period 2001-2006. The survey was sent to all enterprises within selected economic activities that had a hundred or more employees in 2007. A total of 636 enterprises out of 1292 responded to the survey.

We primarily focus on the survey questions related to international sourcing (offshoring). International sourcing is defined in the survey as "the total or partial movement of business functions currently performed in-house or currently domestically sourced by the resident enterprise to either non-affiliated or affiliated enterprise located abroad". This definition of offshoring enables us to construct an accurate and direct measure of whether an enterprise has offshored or not. Further, the survey asked enterprises to distinguish between core and support business functions such as (1) distribution and logistics; (2) marketing, sales and after sales services; (3) ICT services; (4) administrative and management functions; (5) engineering and related technical services; (6) research and development (R\&D); and (7) other types of service support functions. ${ }^{8}$ A subsequent question asks enterprises to identify the country/region where the business function was offshored to. The identified regions/

\footnotetext{
7 The Central Statistics Office (CSO) used the Business Register to identify enterprises with more than 100 employees in 2007.

${ }^{8}$ Core business functions are defined in the ISS as the "production of final goods or services intended for the market/for third parties carried out by the enterprise and yielding income. Core business function equals in most cases the primary activity of the enterprise". Support business functions are defined as those functions which are "carried out in order to permit or facilitate production of goods or services intended for the market/for third parties by the enterprise. The outputs of the support business functions are not themselves intended directly for the market/for third parties".
} 
countries were: EU15, EU12, ${ }^{9}$ other European countries, ${ }^{10}$ China, India, other Asian countries and Oceania, USA and Canada, South and Central America and Africa.

We match the enterprise sourcing data with additional enterprise information taken from the ASI for service enterprises and from the CIP for manufacturing enterprises. The ASI collects service enterprise information annually. It surveys all enterprises with $20+$ employees plus a random sample of the smaller units with 2-19 persons engaged. The sample is stratified by activity (NACE Rev 1.1. classification), employment size class and NUTS2 region. The CIP is a census of all manufacturing, mining and utilities plants. We use data from the more detailed survey which is completed by enterprises with more than 20 persons engaged. From these datasets, we use information on enterprise ownership, value of sales, share of exports in total sales, number of employees, regional location and investment in ICT capital. We take the average of the available data for the enterprise variables over the period 2001-2006 before merging them with the ISS data. Descriptions of the variables used in our analysis are presented in Table 5 in the Appendix.

The analysed data does not allow the establishment of the date when firms' offshoring has started. This implies that, although the identified links between the offshoring propensity and characteristics of firms and sourcing locations may be indicative of causal relationships, they can at best be interpreted as structural links.

The merged data resulted in a sample of 503 enterprises out of the 636 from the International Sourcing Survey. Table 1 presents the average values of the offshoring measure by type of business function offshored for (1) all enterprises; (2) manufactures; and (3) service enterprises. The offshoring measures are binary variables, taking value one if the enterprise offshored a specific business function and zero otherwise. The measure is also broken down by five different types of enterprise in our sample: all enterprises, foreign-owned, domestic-owned enterprises, all exporting firms, and domestic exporters.

A number of interesting results emerge from Table 1. Enterprises integrated in international production networks (foreign-owned and exporters) are more likely to offshore R\&D than domestic-owned enterprises that do not export. Thus, while $15 \%$ of foreign-owned enterprises and $12 \%$ of exporters reported offshoring of R\&D, only $9 \%$ of all firms offshored R\&D. This pattern appears to be driven by manufacturing firms with large shares of firms engaged in international production networks reporting offshoring of R\&D: $22 \%$ of foreign-owned firms, and 14\% of exporters. In comparison, for service firms, the corresponding shares are smaller: $7 \%$ of foreignowned firms and 5\% for exporters. Considering all firms, while $15 \%$ of all manufacturing firms offshored $\mathrm{R} \& \mathrm{D}$, the corresponding share for all service firms is much lower, $4 \%$.

Looking across offshoring of other business functions, Table 1 shows that some business functions are more likely to be offshored than others. Column 1 in Table 1 shows that for all enterprises (the top section of Table 1), the average value of the

\footnotetext{
9 Bulgaria, Cyprus, the Czech Republic, Estonia, Hungary, Latvia, Lithuania, Malta, Poland, Romania, the Slovak Republic, Slovenia.

10 Switzerland, Norway, Turkey, Russia, Belarus, Ukraine and the Balkan states.
} 
Table 1 Offshoring by enterprise type, Ireland, 2001-2006

\begin{tabular}{|c|c|c|c|c|c|}
\hline Offshored business function & All firms & $\begin{array}{l}\text { Foreign- } \\
\text { owned enter- } \\
\text { prises }\end{array}$ & $\begin{array}{l}\text { Domestic- } \\
\text { owned } \\
\text { enterprises }\end{array}$ & $\begin{array}{l}\text { All export- } \\
\text { ing firms }\end{array}$ & $\begin{array}{l}\text { Domestic-owned } \\
\text { exporters }\end{array}$ \\
\hline \multicolumn{6}{|l|}{ All enterprises } \\
\hline Research and development & 0.09 & 0.15 & 0.04 & 0.12 & 0.05 \\
\hline Core & 0.35 & 0.48 & 0.26 & 0.45 & 0.37 \\
\hline Distribution & 0.20 & 0.31 & 0.12 & 0.28 & 0.21 \\
\hline Marketing & 0.16 & 0.24 & 0.1 & 0.19 & 0.14 \\
\hline ICT & 0.15 & 0.25 & 0.07 & 0.17 & 0.08 \\
\hline Administration & 0.11 & 0.20 & 0.04 & 0.12 & 0.05 \\
\hline Engineering & 0.17 & 0.24 & 0.11 & 0.23 & 0.20 \\
\hline Other & 0.03 & 0.03 & 0.03 & 0.02 & 0.01 \\
\hline Observations & 503 & 215 & 288 & 278 & 118 \\
\hline \multicolumn{6}{|l|}{ Services } \\
\hline Research and development & 0.04 & 0.07 & 0.03 & 0.05 & 0.08 \\
\hline Core & 0.25 & 0.39 & 0.19 & 0.33 & 0.35 \\
\hline Distribution & 0.13 & 0.25 & 0.07 & 0.20 & 0.19 \\
\hline Marketing & 0.14 & 0.24 & 0.08 & 0.20 & 0.22 \\
\hline ICT & 0.13 & 0.24 & 0.07 & 0.16 & 0.14 \\
\hline Administration & 0.10 & 0.22 & 0.03 & 0.11 & 0.08 \\
\hline Engineering & 0.11 & 0.19 & 0.06 & 0.15 & 0.19 \\
\hline Other & 0.03 & 0.02 & 0.03 & 0.00 & 0.00 \\
\hline Observations & 303 & 99 & 204 & 92 & 37 \\
\hline \multicolumn{6}{|l|}{ Manufacturing } \\
\hline Research and development & 0.15 & 0.22 & 0.06 & 0.14 & 0.04 \\
\hline Core & 0.50 & 0.55 & 0.43 & 0.49 & 0.40 \\
\hline Distribution & 0.31 & 0.36 & 0.24 & 0.32 & 0.24 \\
\hline Marketing & 0.19 & 0.23 & 0.13 & 0.19 & 0.12 \\
\hline ICT & 0.18 & 0.25 & 0.08 & 0.16 & 0.06 \\
\hline Administration & 0.13 & 0.17 & 0.06 & 0.11 & 0.04 \\
\hline Engineering & 0.26 & 0.28 & 0.23 & 0.26 & 0.21 \\
\hline Other & 0.04 & 0.04 & 0.04 & 0.03 & 0.01 \\
\hline Observations & 200 & 116 & 84 & 176 & 67 \\
\hline
\end{tabular}

Own calculations based on data from the International Sourcing Survey (ISS) 2007. The sample is derived from merging the Annual Services Inquiry (ASI), the Census of Industrial Production (CIP) and the International Sourcing Survey (ISS) datasets provided by the Central Statistics Office of Ireland. The summary measure in each cell is the mean value for each of the binary offshoring measures used in the analysis

offshoring measure ranges from 0.35 down to 0.03 , with core business functions having the highest values, while other business functions have the lowest values. Second, manufacturing enterprises are more likely to offshore each business function compared with services enterprises (based on comparison of middle and bottom section of column 1). Third, there are differences in the ranking of the offshoring 
business function measure for manufacturing and services enterprises. For example, besides the core and distribution functions, which are both high in the ranking of offshoring functions for manufacturing and services, the offshoring of engineering service support functions is more prevalent amongst manufacturing enterprises while the offshoring of marketing, ICT and distribution services are more likely amongst the services enterprises. Finally, offshoring patterns differ according to enterprise ownership characteristics and exporting activity. For the full sample of manufacturing and service enterprise observations (top section of Table 1), we find that foreign-owned enterprises and domestic exporters are more likely to offshore than domestic non-exporting enterprises for each business function, with the exception of the "other" business function category. This pattern holds when we examine service enterprises separately (see the middle section of Table 1). However, for manufacturing enterprises (the bottom section of Table 1), the pattern is not as clear cut, with domestic non-exporting enterprises exhibiting a higher propensity to offshore a number of business functions compared with domestic exporters.

Additional descriptive statistics of the variables used in our analysis are presented in Tables 6 and 7 in the Appendix.

\section{Empirical methodology}

To analyse the determinants of an enterprise's offshoring decision, we estimate the following probit model specified on the basis of the theoretical and empirical background discussed in Sect. 2

$$
\operatorname{Pr}\left(O F F_{i j s c}=1 / Z_{i j}\right)=\Phi\left(Z_{i j} \beta+\delta_{j}+\lambda_{s}+\varphi_{c}+\vartheta_{n}+\varepsilon_{i j s c}\right) .
$$

$\operatorname{Pr}($.$) refers to the probability of the outcome and \Phi$ (.) is the normal cumulative distribution function. The dependent variable $O F F_{i j s c}$ is a binary variable that is equal to one if an enterprise $i$, in sector $j$, offshores a business function $s$ to country $c$ during the analysed period, and it is zero otherwise. $Z$ is a vector of enterprise characteristics which are expected to influence its decision to offshore. The explanatory variables included in the model specification are: size (SIZE), labour productivity (LPROD), wages per employee (WEMP), ICT investment per employee (ICT), ICT usage $^{11}$ (a dummy variable equal to 1 for firms having a website), ownership (FOREIGN), domestic exporter dummy (DOMEXP), and industry competition (HHI).

As discussed in Sect. 2, characteristics of the source country location are likely to influence the firms' decision to offshore. For instance, some countries may have better trade facilitation infrastructure or large pools of skilled labour that increase the feasibility of an enterprise offshoring. We account for these differences in source country characteristics by including source country dummies (i.e. $\varphi_{c}$ ). To control

\footnotetext{
11 We distinguish between inter-firm ICT adoption (measured by ICT investment per employee) and intra-firm ICT usage (proxied by the usage of a website). Haller and Siedschlag (2011) provide more details on the theoretical and empirical underpinnings of this distinction.
} 
for possible effects of enterprise location and industry-specific effects, we include dummy variables for regions ${ }^{12}$ and industries ${ }^{13}\left(\vartheta_{n}\right.$ and $\delta_{j}$, respectively). To account for the type of business function that is offshored, we include dummy variables for each business function type (i.e. $\lambda_{s}$ ). The explanatory variables are averaged over the analysed period, 2001-2006.

To account for potential selection bias, we estimate weighted regressions. To calculate the weights, we first merge the CIP and ASI datasets and then, for each year, we sum the number of enterprises in each two-digit Nace Rev 1.1 industry. For service enterprises, we sum the grossing factor based on the number of enterprises provided in the ASI to calculate the number of enterprises in each two-digit NACE Rev 1.1 service industry. The maximum value of the sum of enterprises in each industry over the period 2001-2006 is taken and divided by the sum of the enterprises in each two-digit NACE Rev 1.1 industry in the regression sample.

In our analysis, we first pool each of the business function offshoring decisions together and estimate how the enterprise characteristics relate to its decision to offshore a business function to a particular country for the full set of our enterprise observations. We next analyse determinants of offshoring of R\&D. To test the robustness of our results to possible collinearity between regressors, we estimate several model specifications introducing gradually the relevant explanatory variables.

To put the results for offshoring of $R \& D$ into perspective, we also estimate separate model specifications for the offshoring of the following business functions: (1) core business activities; (2) distribution and logistics; (3) marketing, sales and after sales services; (4) ICT services; (5) administration and management functions; (6) engineering and related technical services.

\section{Empirical results}

In this section, we compare estimates of determinants of $R \& D$ offshoring with determinants of offshoring of other business functions. We begin with the analysis on the links between enterprise characteristics and offshoring decisions across all firms and all business functions. Next, we discuss the estimates of determinants of $\mathrm{R} \& \mathrm{D}$ offshoring and compare the results with determinants of offshoring of other business functions.

Column 2 in Table 2 presents the estimates of the probit model described by Eq. (1) above where we pool all enterprise observations. Specifically, the dependent variable is a binary variable equal to one if the enterprise offshored a particular business function to a particular destination. The estimates shown in Table 2 are average marginal effects with robust standard errors reported in parentheses. We present the estimation results in a stepwise fashion: an initial set of control variables (column 1) includes employment (taken in logs) as proxy for size, dummy variables for foreign

12 Regions classified as NUTS 2.

13 At the two digit level, NACE Rev. 1.1 classification. 


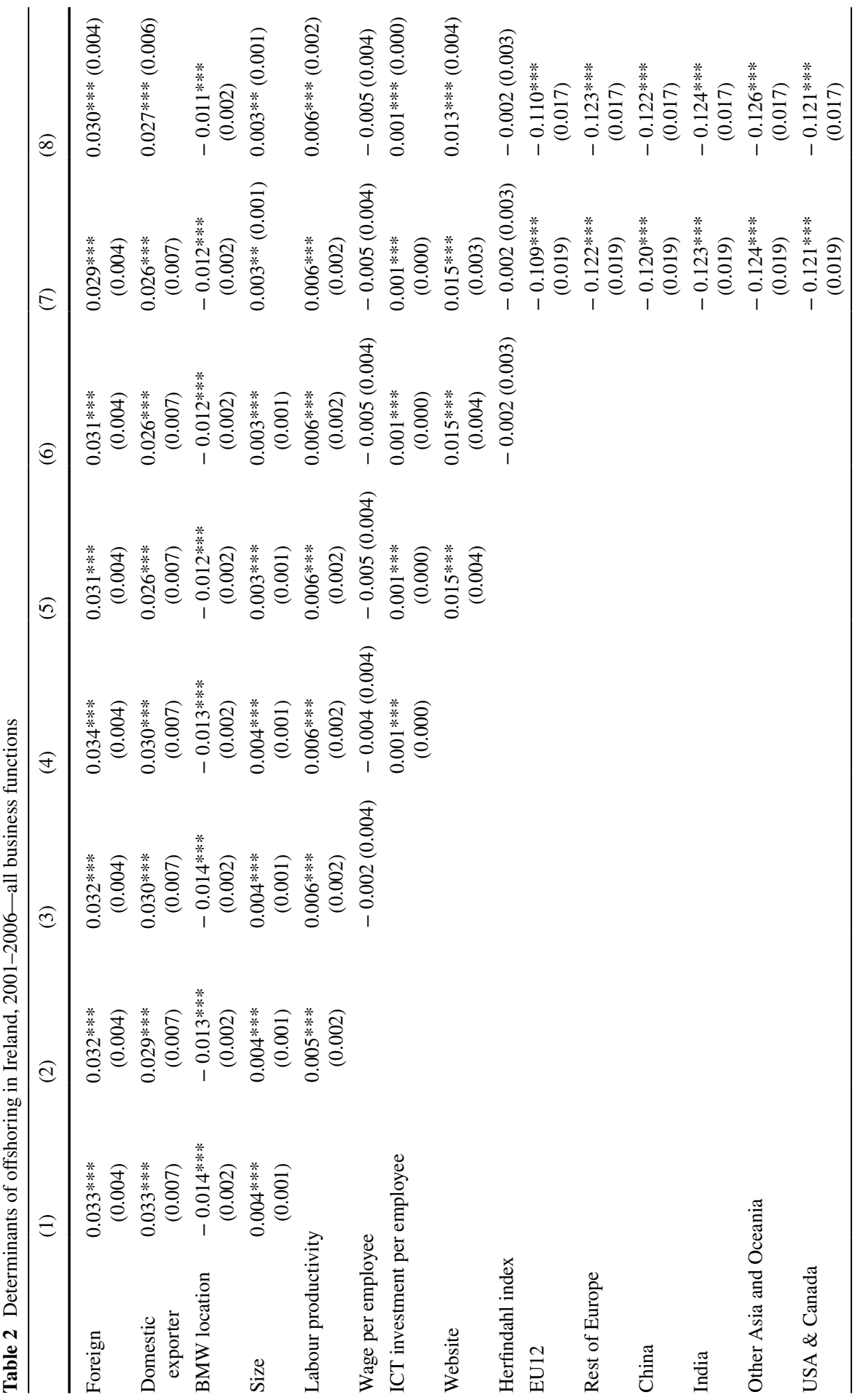




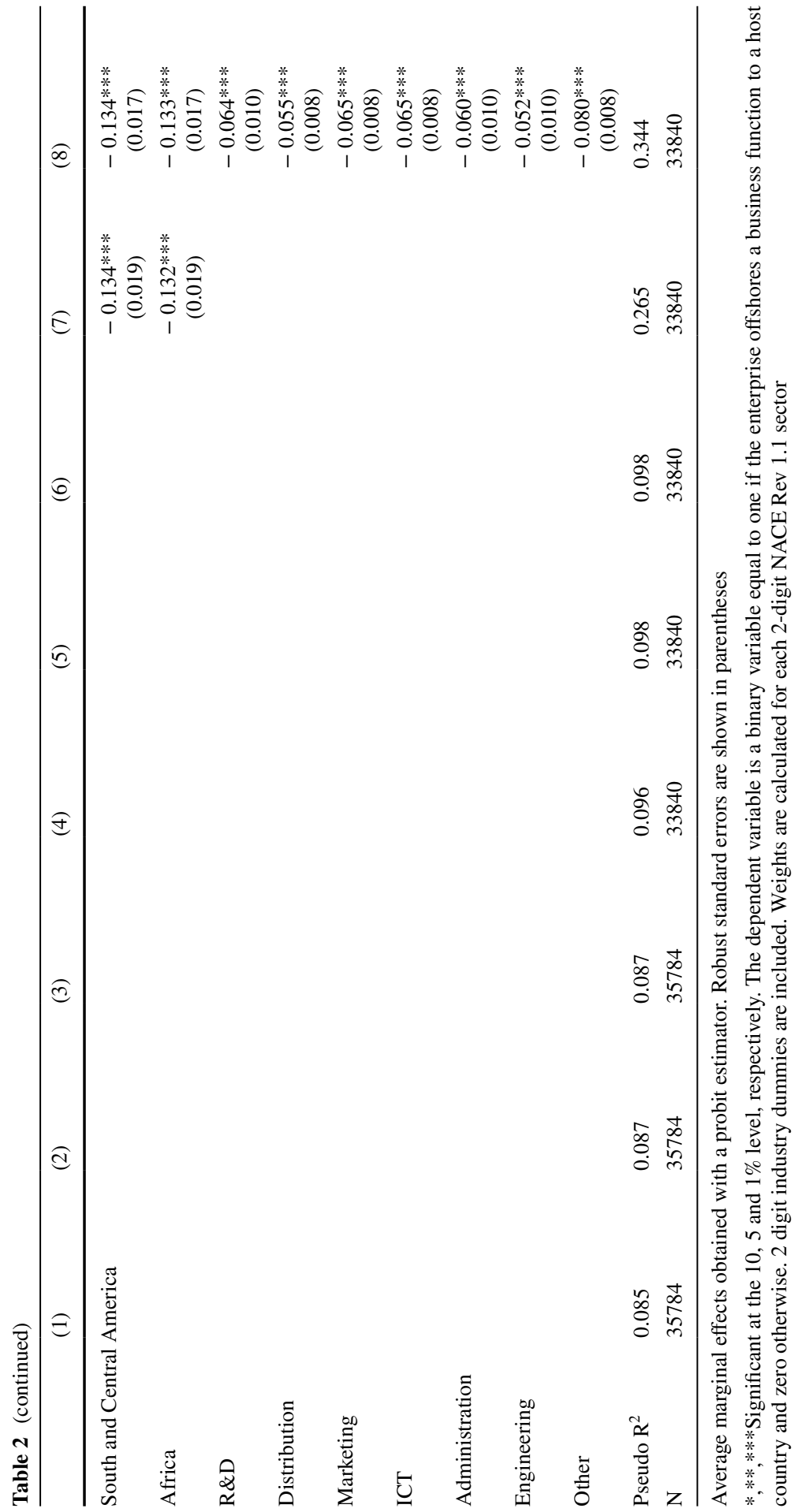


ownership domestic exporters, location within Ireland, as well as industry timeinvariant characteristics. We then add one explanatory variable at a time: labour productivity (column 2), wage per employee as proxy for human capital (column 3), ICT investment intensity (column 4), website (column 5), competition (Herfindahl index, column 6), source regions (column 7), and business functions (column 8). The final column contains the full model specification.

The results shown in Table 2 indicate that larger and more productive enterprises are more likely to offshore business activities. This positive link between an enterprise's productivity and its propensity to trade is well established in the international trade literature. ${ }^{14}$ Furthermore, foreign-owned enterprises and domestic exporters are each 3 percentage points more likely to offshore business activities as compared with domestic enterprises and domestic non-exporters, respectively. The important role of ICT for offshoring appears to be confirmed, with the ICT intensity variable being positively associated with an enterprise's propensity to offshore business activities. Enterprises that have a website are 1.3 percentage points more likely to offshore business activities. We find that enterprises that are located in the Border, Midland and Western (BMW) region have a lower propensity to offshore business activities relative to enterprises located in the Southern and Eastern (SE) region.

The characteristics of the source region controlled for by dummies for the source region are significantly related to the enterprise offshoring behaviour, with offshoring to country/regions outside the EU15 found to be less likely. ${ }^{15}$ This result is unsurprising as the fixed entry costs into offshoring to the EU15 group of countries are likely to be lower given their relative proximity and the strong trade and financial linkages. We also find that offshoring of $R \& D$ is less likely relative to offshoring of core business functions. The marginal effect implies that on average, across all firms, the probability of offshoring of $R \& D$ is lower by 6.4 percentage points relative to the probability of offshoring core business functions. All other support business functions had a lower propensity of being offshored when compared with the omitted reference group, i.e. core business functions. The largest effect is in the case of offshoring of other business functions, with a probability lower by 8 percentage points compared to the probability of offshoring core business functions.

Table 3 reports average marginal effects of determinants of R\&D offshoring obtained with stepwise probit regressions. Overall, the significance and size of the effects of the main determinants of enterprises' propensity to offshore R\&D are robust across the seven model specifications.

Focusing on the full model specification (column 7), the estimates suggest that enterprises with international experience are more likely to offshore R\&D. Being a foreign-owned enterprise increases the propensity of offshoring $R \& D$ by 3

\footnotetext{
${ }^{14}$ Most of the research in this area has focused on the link between productivity and the exporting of goods. Recent research by Vogel and Wagner (2010) has found a positive link between productivity and importing. Also, Biewen et al. (2012) find evidence that more productive firms are more likely to import services from abroad.

15 Given the important economic ties between Ireland and the UK, it would have been particularly useful if the survey separated the UK from the other EU15 member states. We could then have examined if the strong ties with Ireland-UK were driving this result.
} 


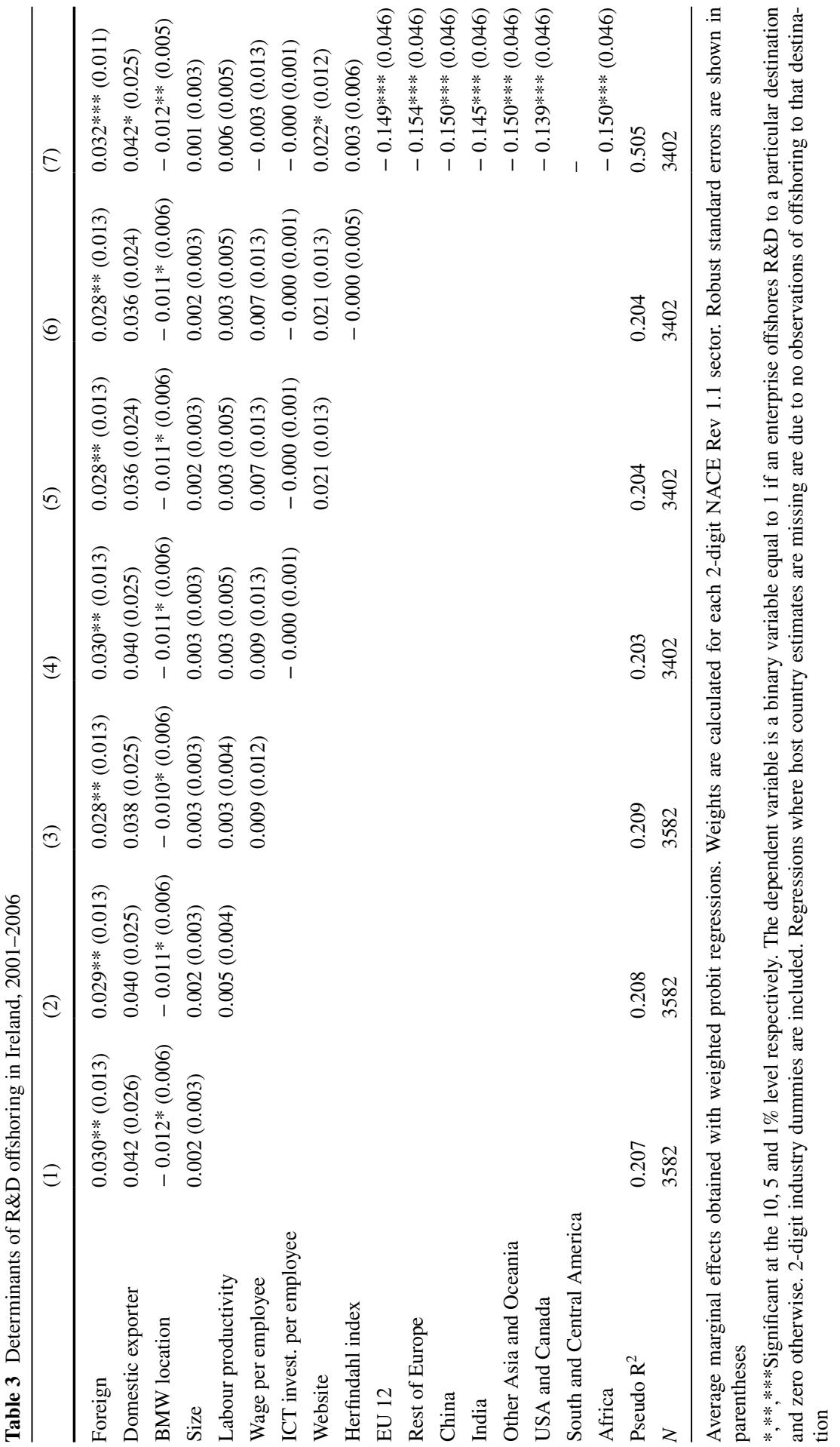


percentage points, while domestic exporters are more likely to offshore R\&D by 4 percentage points. Furthermore, having a website increases the probability of offshoring R\&D by 2 percentage points. This result appears to be conditioned by controls for the source regions. Being located in the BMW region reduces the likelihood of $\mathrm{R} \& \mathrm{D}$ offshoring by 1.2 percentage points relative to enterprises located in the Southern and Eastern region (which includes the capital city). The strength of this link increases when control variables for source regions are included in the regression. With respect to source regions, the results indicate that Ireland's offshoring of $\mathrm{R} \& \mathrm{D}$ is less likely from any region outside the EU15. The probabilities to source R\&D from locations other than the EU15 are lower by 1.4-1.5 percentage points relative to the probability to source R\&D from EU15. The other analysed determinants do not appear to have impacted significantly on the enterprises' decision to offshore R\&D.

Table 4 compares the estimates of determinants of R\&D offshoring reported in column 7 in Table 3 with estimates for other offshored business functions. ${ }^{16}$ The dependent variable is a binary variable equal to one if the enterprise offshored the respective business function to a particular destination and equal to zero if it did not.

The results reported in columns 2-7 indicate that, as in the case of R\&D offshoring, foreign-owned enterprises had a relatively greater propensity to offshore each type of business function. The marginal effects for offshoring any of the other business functions are larger than in the case of R\&D offshoring, ranging from 3.5 percentage points in the case of offshoring of marketing activities to 6.8 percentage points in the case of offshoring of distribution activities. Domestic exporters are more likely than firms with no international activities to offshore any of the support business functions. However, this is not true for offshoring of core functions. The lowest effect is found for offshoring of marketing (2.6 percentage points), and the largest in the case of distribution functions (9.5 percentage points). Further, our results indicate that while size and productivity did not appear to matter for offshoring of $\mathrm{R} \& \mathrm{D}$, larger enterprises were more likely to offshore distribution, marketing, ICT, and administration functions and more productive enterprises were more likely to offshored distribution and marketing functions.

The intensity of investment in ICT intensity is positively associated only with an enterprise's propensity to offshore core business functions. Enterprises with a website had a relatively greater propensity to offshore core, ICT, engineering, and R\&D activities. We continue to find that the propensity to offshore to destinations outside of the EU15 was lower. Also, enterprises located in the BMW region were less likely to offshore core, distribution, engineering, and R\&D business functions.

Taken together, our research suggests that offshoring of R\&D is a similar strategic choice as offshoring core business and engineering activities. In contrast, with the exception of foreign-ownership, determinants of R\&D offshoring differ from those for offshoring of support business functions such as distribution, marketing, ICT and administration.

\footnotetext{
${ }^{16}$ The model specification for 'other' business could not be estimated due to collinearity and sample size.
} 


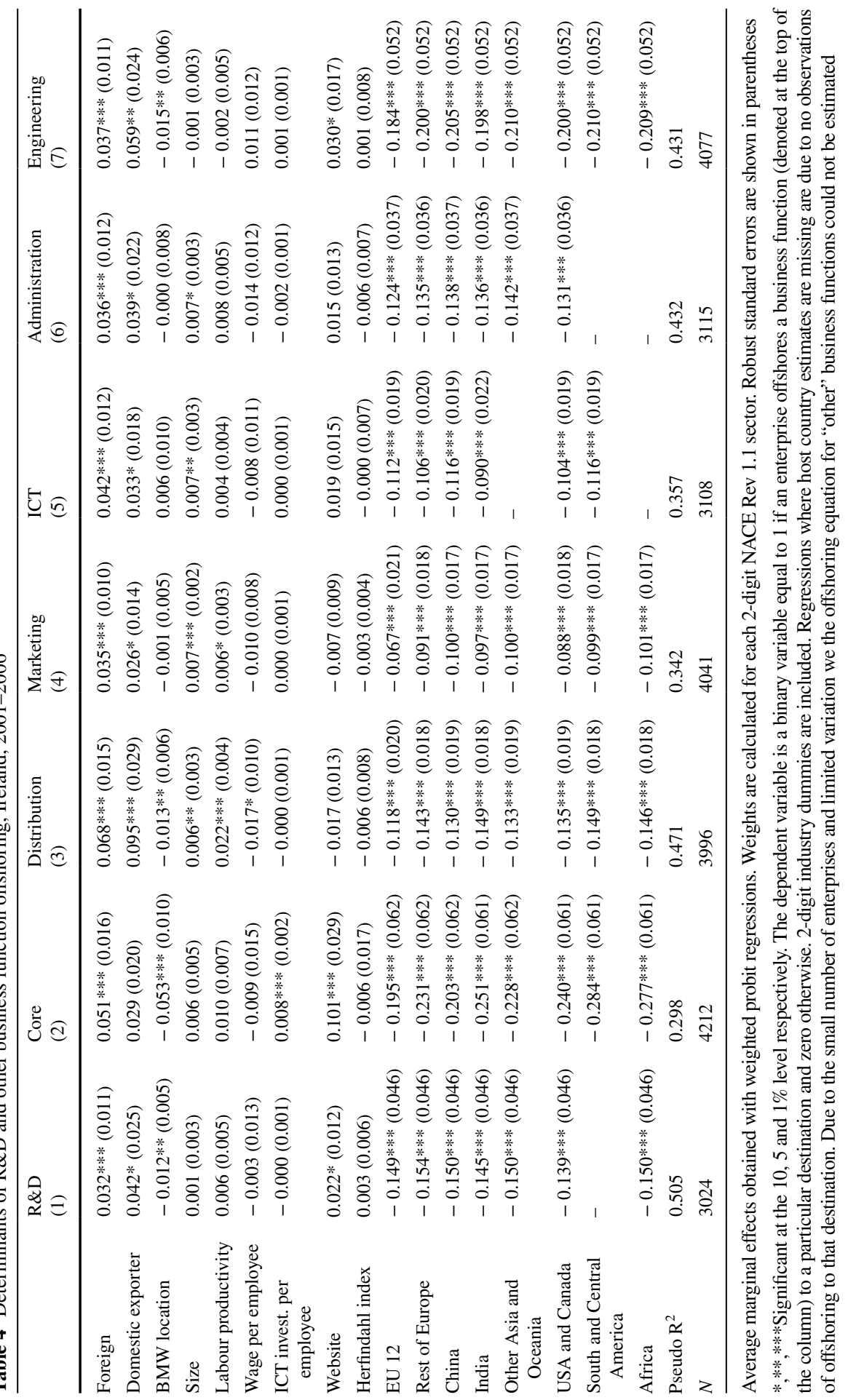




\section{Conclusions}

In this paper we investigated the factors that are expected to influence an enterprise's decision to offshore R\&D and other business functions. More specifically, using Irish survey data for the period 2001-2006 for over 500 enterprises we identify and quantify internal and external factors that influence an enterprise's propensity to offshore $R \& D$ and other types of core activities as well as support business functions such as distribution, marketing, ICT, administration, and engineering.

Our results can be summarised as follows. When pooling together all business functions, we find that on average, other things equal, the likelihood of offshoring business activities is positively associated with an enterprise's size and labour productivity. Furthermore, international experience and linkages through foreignownership and exporting increased the likelihood of offshoring. ICT intensity and ICT usage were also found to matter, with ICT investment per employee and having a website being positively associated with an enterprise's propensity to offshore business activities. Further, we find that core business functions were more likely to be offshored compared with support service functions. The source regions were also important, with the propensity to offshore to destinations outside of the advanced economies of the EU (EU15) being lower. This result is consistent with the role that distance as well as the quality of institutions play in lowering transaction and information costs associated with offshoring.

Offshoring of R\&D is less likely by 6.4 percentage points than offshoring of core business activities. This result suggests the relatively more strategic importance of R\&D activities. Further, our estimates suggest that enterprises with international experience are more likely to offshore R\&D. Being a foreign-owned enterprise increases the propensity of offshoring of R\&D by 3 percentage points, while exporters are more likely to offshore R\&D by 4 percentage points. Having a website increases the probability of offshoring R\&D by nearly 2 percentage points. With respect to the location of the headquarters, enterprises located in the Border, Midlands, Western (BMW) region are less likely to offshore R\&D relative to those located in the Southern and Eastern region (which includes the capital city). With respect to sourcing locations, it appears that Ireland's offshoring of R\&D is less likely from any other region than EU15. This result suggest that offshoring of $\mathrm{R} \& \mathrm{D}$ is likely to be driven by knowledge and technology sourcing from other advanced economies.

Comparing the estimates for determinants of offshoring other business functions, our research suggests that offshoring of $R \& D$ is a similar strategic choice as offshoring core business and engineering activities. In contrast, with the exception of foreign-ownership, determinants of $R \& D$ offshoring differ from those for offshoring of support business functions such as distribution, marketing, ICT and administration.

These research results help to understand the growing internationalisation of R\&D activities. More specifically, this empirical analysis provides novel evidence on the internal and external factors which influence the propensity of enterprise 
to offshore R\&D and more generally, on the factors driving the integration of firms in international production and innovation networks. This evidence informs enterprise strategy and policy design that seeks to maximise the benefits from international sourcing and global value chains.

Our evidence suggests that to the extent that increasing the internationalisation of $\mathrm{R} \& \mathrm{D}$ is a desirable policy objective, measures aimed at fostering enterprises' engagement in global markets and usage of ICT would increase the likelihood of sourcing R\&D internationally. Further research could examine in more depth whether offshoring of R\&D and offshoring of other business activities are complementary or substitutes and to what extent offshoring of R\&D increases enterprises' innovation and productivity performance.

Open Access This article is distributed under the terms of the Creative Commons Attribution 4.0 International License (http://creativecommons.org/licenses/by/4.0/), which permits unrestricted use, distribution, and reproduction in any medium, provided you give appropriate credit to the original author(s) and the source, provide a link to the Creative Commons license, and indicate if changes were made.

\section{Appendix}

See Tables 5, 6, 7. 


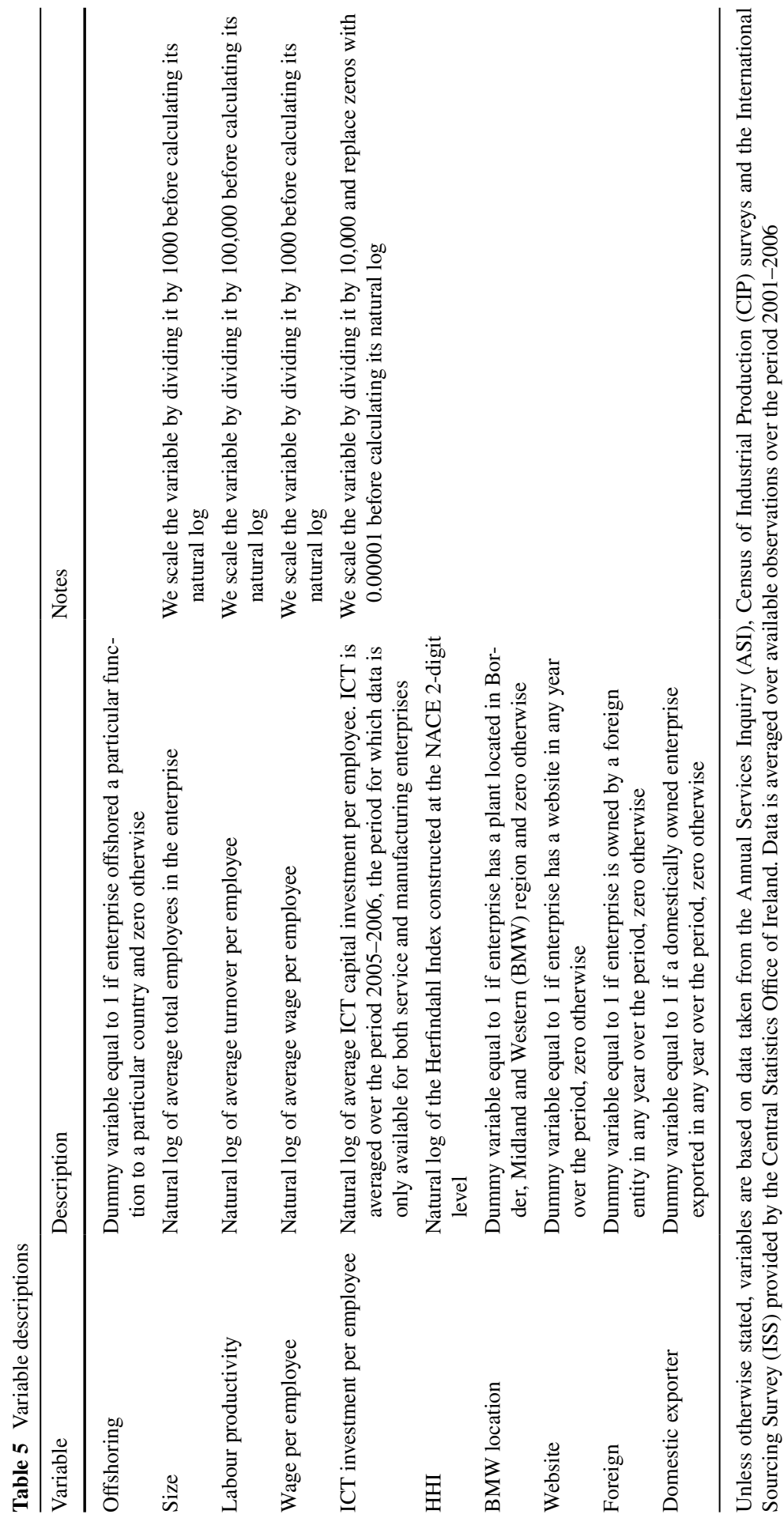


Table 6 Descriptive statistics

\begin{tabular}{|c|c|c|c|c|c|}
\hline Variable & Obs. & Mean & Std. dev & Min & Max \\
\hline \multicolumn{6}{|l|}{ All enterprises } \\
\hline Number of employees ('000) & 503 & 0.36 & 0.68 & 0.00 & 9.99 \\
\hline Labour productivity (log) & 503 & 11.94 & 1.14 & 9.29 & 16.03 \\
\hline Wage per employee (log) & 503 & 3.31 & 0.49 & 0.94 & 5.73 \\
\hline ICT capital investment per employee ('000) & 503 & 0.70 & 1.40 & 0.00 & 11.15 \\
\hline Exports per turnover & 503 & 0.30 & 0.41 & 0.00 & 1.00 \\
\hline Website & 503 & 0.91 & 0.29 & 0.00 & 1.00 \\
\hline Herfindahl index & 503 & 0.07 & 0.11 & 0.00 & 0.97 \\
\hline Foreign & 503 & 0.43 & 0.49 & 0.00 & 1.00 \\
\hline Domestic exporter & 503 & 0.23 & 0.42 & 0.00 & 1.00 \\
\hline BMW location & 503 & 0.18 & 0.39 & 0.00 & 1.00 \\
\hline \multicolumn{6}{|l|}{ Services } \\
\hline Number of employees ('000) & 303 & 0.38 & 0.82 & 0.00 & 9.99 \\
\hline Labour productivity (log) & 303 & 11.67 & 1.18 & 9.29 & 15.88 \\
\hline Wage per employee (log) & 303 & 3.22 & 0.54 & 1.65 & 5.73 \\
\hline ICT capital investment per employee ('000) & 303 & 0.60 & 1.20 & 0.00 & 9.90 \\
\hline Exports per turnover & 303 & 0.09 & 0.24 & 0.00 & 1.00 \\
\hline Website & 303 & 0.86 & 0.34 & 0.00 & 1.00 \\
\hline Herfindahl index & 303 & 0.03 & 0.08 & 0.00 & 0.57 \\
\hline Foreign & 303 & 0.33 & 0.47 & 0.00 & 1.00 \\
\hline Domestic exporter & 303 & 0.16 & 0.36 & 0.00 & 1.00 \\
\hline BMW location & 303 & 0.12 & 0.33 & 0.00 & 1.00 \\
\hline \multicolumn{6}{|l|}{ Manufacturing } \\
\hline Number of employees ('000) & 200 & 0.32 & 0.40 & 0.01 & 3.77 \\
\hline Labour productivity (log) & 200 & 12.35 & 0.96 & 9.83 & 16.02 \\
\hline Wage per employee ('log) & 200 & 3.44 & 0.36 & 0.94 & 4.23 \\
\hline ICT capital investment per employee ('000) & 200 & 0.80 & 1.60 & 0.00 & 11.50 \\
\hline Exports per turnover & 200 & 0.63 & 0.41 & 0.00 & 1.00 \\
\hline Website & 200 & 0.98 & 0.14 & 0.00 & 1.00 \\
\hline Herfindahl index & 200 & 0.13 & 0.12 & 0.01 & 0.97 \\
\hline Foreign & 200 & 0.58 & 0.49 & 0.00 & 1.00 \\
\hline Domestic exporter & 200 & 0.36 & 0.48 & 0.00 & 1.00 \\
\hline BMW location & 200 & 0.28 & 0.45 & 0.00 & 1.00 \\
\hline
\end{tabular}

Source: own calculations based on data taken from the Annual Services Inquiry (ASI), Census of Industrial Production (CIP) surveys and International Sourcing Survey (ISS) provided by the Central Statistics Office of Ireland. Data is averaged over available observations over the period 2001-2006 


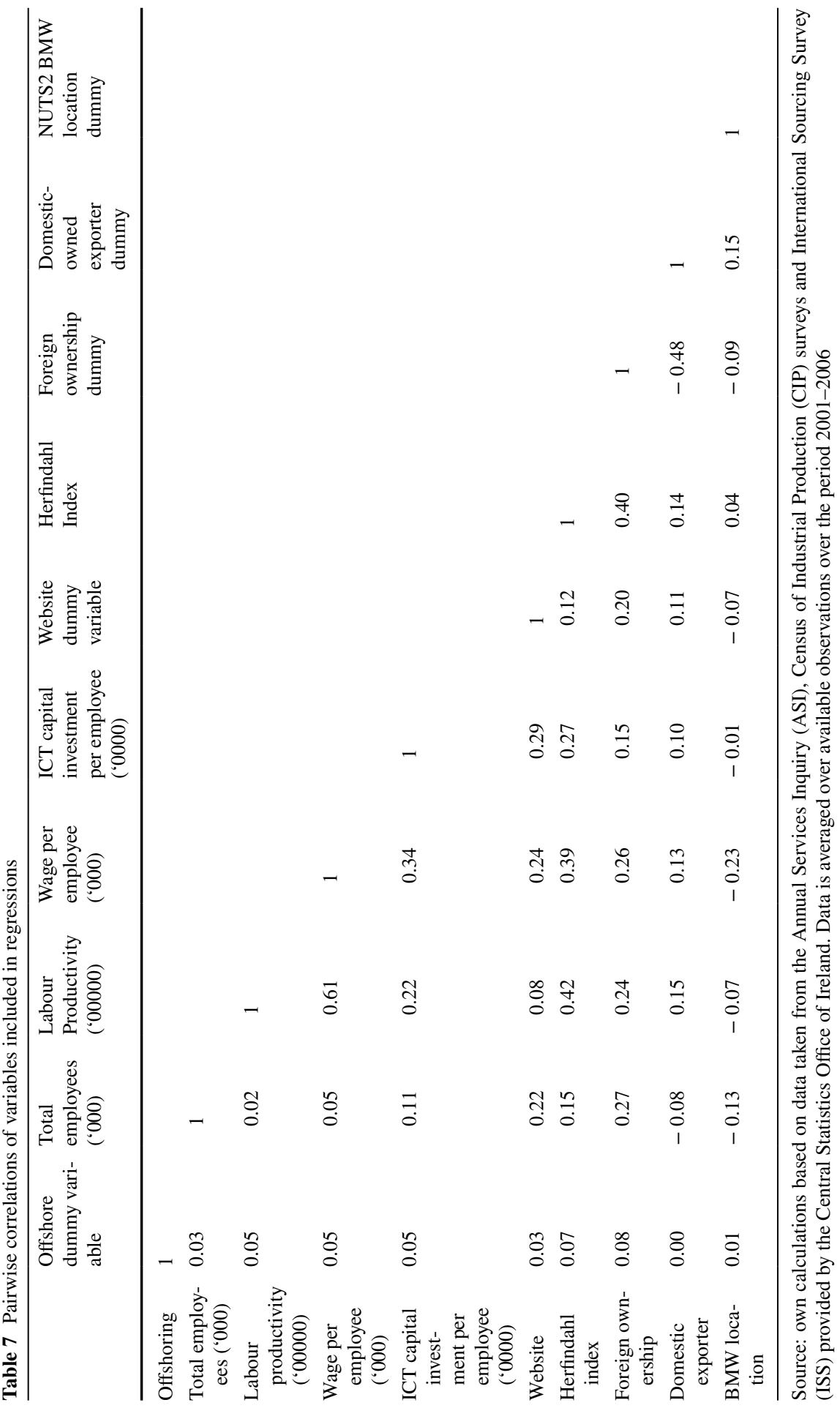




\section{References}

Abramovsky, L., \& Griffith, R. (2006). Outsourcing and offshoring of business services: How important is ICT? Journal of the European Economic Association, 4(2-3), 594-601.

Abramovsky, L., Griffith, R., Macartney, G., \& Miller, H. (2008). The location of innovative activity in Europe. The Institute for Fiscal Studies Working Paper 08/10.

Alajääskö, P. (2009). International sourcing in Europe. Statistics in Focus 4/2009, Eurostat. http:// ec.europa.eu.

Ambos, B. (2005). Foreign direct investment in industrial research and development: A study of German MNCs. Research Policy, 34(4), 395-410.

Antràs, P., \& Helpman, E. (2004). Global sourcing. Journal of Political Economy, 112(3), 552-580.

Autor, D. H., Levy, F., \& Murnane, R. J. (2003). The skill content of recent technological change: An empirical exploration. Quarterly Journal of Economics, 118(4), 1279-1333.

Bardhan, A. D. (2006). Managing globalization of R\&D: Organizing for offshoring innovation. Human System Management, 25(2), 103-114.

Belderbos, R., Lykogianni, E., \& Veugelers, R. (2008). Strategic R\&D location in European manufacturing industries. Review of World Economics, 144(2), 183-206.

Benfratello, L., Razzolini, T., \& Sembenelli, A. (2009). Does ICT investment spur or hamper offshoring? Empirical evidence from microdata. Department of Economics and Public Finance, "G. Prato" Working Paper Series, University of Torino, No. 5.

Biewen, E., Harsch, D., \& Spies, J. (2012). The determinants of service imports: The role of cost pressure and financial constraints. Deutsche Bundesbank Discussion Paper 31.

Bunyaratavej, K., Hahn, E. D., \& Doh, J. P. (2007). International offshoring of services: A parity study. Journal of International Management, 13(1), 7-21.

Cantwell, J., \& Mundambi, R. (2005). MNE competence-creating subsidiary mandates. Strategic Management Journal, 26(12), 1109-1128.

Ceci, F., \& Masciarelli, F. (2010). A matter of coherence: The effects of offshoring of intangibles on enterprise performance. Industry and Innovation, 17(4), 373-392.

Cesaroni, F. (2004). Technological outsourcing and product diversification: Do markets for technology affect firm strategies? Research Policy, 33(10), 1547-1564.

Coase, R. H. (1937). The nature of the firm. Econometrica, 4(16), 386-405.

Dachs, B. (2014). Internationalisation of R\&D: A brief survey of the literature. In B. Dachs, R. Stehrer, \& G. Zahradnik (Eds.), The internationalisation of business $R \& D$ (pp. 5-26). Cheltenham: Edward Elgar.

Farrell, D., Laboissiere, M. A., \& Rosenfeld, J. (2006). Sizing the emerging global labor market: Rational behavior from both companies and countries can help it work more efficiently. Academy of Management Perspectives, 20(4), 23-34.

García-Vega, M., \& Huergo, E. (2011). Determinants of international R\&D outsourcing: The role of trade. Review of Development Economics, 15(1), 93-107.

Görg, H., Greenaway, D., \& Kneller, R. (2008). The economic impact of offshoring. GEP Research Report, Leverhulme Centre for Research on Globalisation and Economic Policy, University of Nottingham, June.

Grossman, G., \& Helpman, E. (2002). Integration versus outsourcing in industry equilibrium. Quarterly Journal of Economics, 117(1), 85-120.

Grossman, G. M., \& Rossi-Hansberg, E. (2008). Trading tasks: A simple theory of offshoring. American Economic Review, 98(5), 1978-1997.

Haller, S. A., \& Siedschlag, I. (2011). Determinants of ICT adoption: Evidence from firm-level data. Applied Economics, 43(26), 3775-3788.

Helpman, E., Melitz, M. J., \& Yeaple, S. P. (2004). Trade, FDI, and the organisation of firms. Journal of Economic Literature, XLIV, 589-630.

Ito, B., \& Wakasugi, R. (2007). What factors determine the mode of overseas R\&D by multinationals? Empirical evidence. Research Policy, 36(8), 1275-1287.

Iwasa, T., \& Odagiri, H. (2004). Overseas R\&D, knowledge sourcing, and patenting: An empirical study of Japanese R\&D investment in the US. Research Policy, 33(5), 807-828.

Jabbour, L., \& Zuniga, P. (2009). Drivers of the offshore outsourcing of R\&D: Empirical evidence from French manufacturers. The University of Nottingham, Research Paper Series. https://doi. org/10.2139/ssrn.1367327. 
Jabbour, L., \& Zuniga, P. (2016). "The outsourcing of research and development in global markets: Evidence from France. The World Economy, 39(3), 339-368.

Kuemmerle, W. (1999). The drivers of foreign direct investment into research and development: An empirical investigation. Journal of International Business Studies, 30(1), 1-24.

Le Bas, C., \& Sierra, C. (2002). "Location versus home country advantages in R\&D activities: Some further results on multinationals' location strategies. Research Policy, 31(4), 589-609.

Lewin, A. Y., Massini, S., \& Peeters, C. (2009). "Why are companies offshoring innovation? The emerging global race for talent. Journal of International Business Studies, 40(6), 901-925.

Manning, S., Massini, S., \& Lewin, A. Y. (2008). A dynamic perspective on next-generation offshoring: The global sourcing of science and engineering skills. Academy of Management Perspectives, 22(3), $35-54$.

Martinez-Noya, A., Garcia-Canal, E., \& Guillen, M. F. (2012). International R\&D services outsourcing by technology-intensive firms: Whether and where? Journal of International Management, 18(1), $18-37$.

Nieto, M. J., \& Rodríguez, A. (2011). Offshoring of R\&D: Looking abroad to improve innovation performance. Journal of International Business Studies, 42(3), 345-361.

Nordås, H. K. (2006). Time as a trade barrier: Implications for low-income countries. OECD Economic Studies No. 42.

OECD. (2008). The internationalisation of business $R \& D$ : Evidence, impacts and implications. Paris: OECD Publishing.

Patel, P., \& Vega, M. (1999). Patterns of internationalisation of corporate technology: location vs. home country advantages. Research Policy, 28, 145-155.

Rae, D., \& Sollie, M. (2008). Globalisation and the European Union: Which countries are best placed to cope? OECD Economics Department Working Paper No. 586.

Rasel, F. (2012). Offshoring and ICT-Evidence for German manufacturing and service firms. ZEW, Centre for European Economic Research Discussion Paper No. 12-087.

Sachwald, F. (2008). Location choice within global innovation networks: The case of Europe. Journal of Technology Transfer, 33(4), 364-378.

Shimizutani, S., \& Todo, Y. (2008). What determines overseas R\&D activities? The case of Japanese multinational firms. Research Policy, 37(3), 530-544.

Siedschlag, I., Smith, D., Turcu, C., \& Zhang, X. (2013). What determines the location choice of R\&D activities by multinational firms? Research Policy, 42(8), 1420-1430.

Tamayo, M. P., \& Huergo, E. (2017). Determinants of internal and external R\&D offshoring: Evidence from Spanish firms. Industry and Innovation, 24(2), 143-164.

Tomiura, E. (2005). Foreign outsourcing and firm-level characteristics: Evidence from Japanese manufacturers. Journal of the Japanese and International Economies, 19(2), 255-271.

Veugelers, R. (1997). Internal R\&D expenditures and external R\&D sourcing”. Research Policy, 26(3), 303-315.

Veugelers, R., \& Cassiman, B. (1999). Make and buy in innovation strategies: Evidence from Belgian manufacturing firms. Research Policy, 28(1), 63-80.

Vogel, A., \& Wagner, J. (2010). Higher productivity in importing German manufacturing firms: Self selection, learning from importing, or both? Review of World Economics (Weltwirtschaftliches Archiv), 145(4), 641-665.

von Zedtwitz, M., \& Gassmann, O. (2002). Market versus technology drive in R\&D internationalization: Four different patterns of managing research and development. Research Policy, 31(4), 569-588.

Wagner, J. (2011). Offshoring and enterprise performance: Self-selection, effects on performance, or both? Review of World Economics (Weltwirtschaftliches Archiv), 147(2), 217-247. 